\section{Mechanical Thinning of Mandarins with a Branch Shaker}

\author{
Coral Ortiz ${ }^{1}$, Antonio Torregrosa ${ }^{1}$, Enrique Ortí ${ }^{1}$, \\ and Sebastià Balasch ${ }^{2}$
}

AdDitional Index words. Citrus reticulata, mechanization, operation

SUMMARY. Thinning is the process of removing some flowers or fruit to increase fruit size at harvest. In the Valencia region of Spain, the thinning operation for citrus fruit (Citreae) is performed for some mandarin varieties. This is always performed manually; however, this method is very expensive. The goal of this research study was to assess the mechanical thinning of mandarin (Citrus reticulata) using a handheld branch shaker. Different thinning treatments were conducted over a 3-year period. The gasoline-powered branch shaker was capable of detaching fruit four- to five-times faster than manual thinning. Final fruit size was significantly higher using manual and mechanical thinning compared with a no thinning treatment. Similar final fruit size was obtained with manual and mechanical thinning. However, no significant differences were found in final fruit yield by weight among no thinning, mechanical thinning, and manual thinning treatments. The use of a branch shaker could be recommended for thinning operations to increase efficiency, reduce labor costs, and obtain larger and higher-quality fruit.

$\mathrm{T}$ The final size of citrus (Citreae) fruit depends on the degree of competition among them and other factors related to the resources available to the tree. Larger numbers of flowers and fruit increase competition. This competition reduces the total growth and final size of the fruit (Agustí and Almela, 1984; Agustí et al., 2003; Mesejo et al., 2003). To decrease this competition, "thinning," which is the removal of some flowers and/or fruit in the earliest development stage, is a common practice. Regardless of this, the economic implications of increasing the fruit size and the accompanying

Received for publication 3 July 2019. Accepted for publication 7 Oct. 2020

Published online 6 November 2020

${ }^{1}$ Rural and Agri-food Engineering Department, Universitat Politècnica de València, Valencia 46022, Spain

${ }^{2}$ Applied Statistics and Operational Research Department, Universitat Politècnica de València, Valencia 46022, Spain

This work was supported by funding from the Instituto Nacional de Investigaciones Agrarias (INIA) and European FEDER (Project RTA2014-00025-C05-02). Fontestat provided the experimental fields.

We extend special thanks to technicians Federico Izquierdo and Joan Borrás and to UPV technicians Montano Pérez, Juan José Peña, and Diego Guerra. We thank Clare Treleaven for her English language revision of the manuscript.

C.O. is the corresponding author. E-mail: cortiz@ dmta.upv.es.

This is an open access article distributed under the CC BY-NC-ND license (https://creativecommons.org/ licenses/by-nc-nd/4.0/).

https://doi.org/10.21273/HORTTECH04451-20 reduction of fruit yield by weight have not been deeply studied (Davis et al., 2004).

The main methods of thinning are manual, chemical, and mechanical. Manual thinning is the most frequently used because it is easily adapted to different growing conditions; however, it is slow and expensive. As a result, chemical and mechanical thinning methods are being explored.

Several studies of the chemical thinning of citrus have been conducted (González-Rossia et al., 2007; Guardiola and García-Luis, 2000; Stover et al., 2002). For citrus crops, thinning should be performed during the first stage of fruit development. The compounds most commonly used are naphthalene acetic acid, 2-chloroethyl-phosphonic acid, gibberellic acid, and other synthetic auxins (Agustí, 2003; Mesejo et al., 2012). However, several agrochemical products are being rejected by the market (Ouma, 2012), and their effects are highly variable and strongly influenced by uncontrolled factors, particularly environmental conditions (Greene and Costa, 2013). These observations encourage the exploration of other thinning options such as mechanical procedures.

Mechanical thinning is, to some extent, used for stone fruit (Amygdaleae) and pome fruit (Maleae). However, it has not been adapted to citrus crops. Trunk shakers, among other mechanical systems, have been tested (Berlage and Langmo, 1982; Powell et al., 1975), but the results of trunk shakers, in terms of reducing the number of fruit, have not been shown to be viable. Other authors, including Diezma and Rosa (2005) and Glozer and Hasey (2006), have explored low-frequency, electrodynamic manual shakers, but these have been shown to be impractical. At present, the most commonly used mechanical systems are based on rotatory strings, which are either coupled to a tractor or manually controlled (Damarow et al., 2007; Roche and Masseron, 2002). These mechanisms work well for flower thinning. Mechanical combs used for olive (Olea europaea) harvesting are also being used with some success for flowers and small peach (Prunus persica) fruitlets (Martín et al., 2010). Because leaves are present, these finger and string-based systems cannot be used with citrus fruit as part of thinning operations. Schupp et al. (2008) showed that mechanical thinning using a drum shaker could be highly effective for thinning apple trees (Malus $\times$ domestica) and peach trees grown on production systems trained to a narrow tree wall canopy.

Some studies using manual gasoline-powered shakers and electric combs for thinning mandarins (Citrus reticulata) of the varieties Clemenrubí and Clemenules have been performed. These tests showed that it is possible to detach small fruit (Ortiz et al., 2016, 2017; Torregrosa et al., 2017). However, more

\begin{tabular}{lllc}
\hline $\begin{array}{l}\text { Units } \\
\text { To convert U.S. to SI, } \\
\text { multiply by }\end{array}$ & U.S. unit & SI unit & $\begin{array}{l}\text { To convert SI to U.S., } \\
\text { multiply by }\end{array}$ \\
\hline 0.4047 & $\mathrm{acre}(\mathrm{s})$ & $\mathrm{ha}$ & 2.4711 \\
0.3048 & $\mathrm{ft}$ & $\mathrm{m}$ & 3.2808 \\
0.0283 & $\mathrm{ft}^{3}$ & $\mathrm{~m}^{3}$ & 35.3147 \\
25.4 & inch(es) & $\mathrm{mm}$ & 0.0394 \\
0.4536 & $\mathrm{lb}$ & $\mathrm{kg}$ & 2.2046 \\
28.3495 & $\mathrm{oz}$ & $\mathrm{g}$ & 0.0353
\end{tabular}

\footnotetext{
Horthanglo
} 
exhaustive studies should be undertaken to evaluate the economic validity of these methods.

The overall objective of this work was to study the feasibility of mechanical thinning as an alternative to manual thinning for citrus crops. The specific objectives were to compare the costs of mechanical and manual thinning and to assess the effects on the final fruit yield by weight and fruit size with manual thinning, mechanical thinning, and no thinning.

\section{Material and methods}

ORCHARD DESCRIPTION. Trials were performed in a mandarin orchard located in Sagunto (Valencia, Spain). The trees were planted in a grid with in-row spacing of 2 and $5.1 \mathrm{~m}$ between rows (980 trees/ha). Rows were on trapezoidal ridges. A tractor-mounted ridge machine had been used to construct the berms commonly found in the citrus orchards of the Valencia region $(0.5 \mathrm{~m}$ in height and $1.5 \mathrm{~m}$ wide at the top). Trees were 'Clemenrubi' mandarin topworked onto 'Salustiano' sweet orange (Citrus sinensis) on 'Carrizo' citrange $(C$. sinensis $\times$ Poncirus trifoliata) rootstock. The age of the trees ranged from 8 to 10 years from initial planting. The trunk height was (mean $\pm \mathrm{SD}) 0.45 \pm 0.05 \mathrm{~m}$ and the trunk diameter was $0.11 \pm 0.01 \mathrm{~m}$. The trees had three to five main branches. The canopy height of the aboveground level was $2.2 \pm 0.2 \mathrm{~m}$. The height from the ground to the canopy skirt was 0.9 $\pm 0.2 \mathrm{~m}$. The canopy diameter perpendicular to the row was $2.5 \pm 0.2 \mathrm{~m}$. The canopy diameter parallel to the row was $2.2 \pm 0.2 \mathrm{~m}$. The equivalent canopy volume was $6.8 \pm 1.3 \mathrm{~m}^{3}$.

ThinNING PROCEDURES. In 2016, three treatments, additional manual thinning, mechanical thinning, and no thinning, were performed after a previous manual thinning operation. The smallest fruit were removed by the operator in the case of manual thinning.

During 2017 and 2018, a complete experimental design for comparing manual thinning, mechanical thinning, and no thinning without a previous manual thinning operation, was developed. In 2017, 17 randomly chosen trees were tested. In 2018, 60 trees were tested from the same field (Table 1).

Table 1. Number of tested trees and fruit tested for every year and thinning treatment for 'Clemenrubi' mandarin.

\begin{tabular}{lccc}
\hline Yr & Thinning treatment $^{z}$ & Tested trees (no.) & Tested fruit at harvest (no.) $^{2}$ \\
\hline 2016 & N & 7 & 350 \\
& V & 3 & 150 \\
2017 & M & 4 & 200 \\
& N & 7 & 350 \\
\multirow{2}{*}{2018} & V & 6 & 300 \\
& M & 4 & 200 \\
& N & 18 & 900 \\
& M & 16 & 700 \\
\hline
\end{tabular}

${ }^{\mathrm{z}} \mathrm{N}=$ no thinning, $\mathrm{V}=$ vibratory mechanical thinning, $\mathrm{M}=$ manual thinning.

The manual thinning procedure was performed by detaching fruit according to size; the smallest fruit were manually picked. In 2016, the manual thinning operation was performed by experienced operators according to a size criterion (smaller than $20 \mathrm{~mm}$ during the first pass and smaller than $30 \mathrm{~mm}$ during the second pass. However, in 2017 and 2018, the thinning operation was performed by detaching a fixed number of the smallest fruit (100 fruit/ tree were picked on 25 July 2017 and 90 fruit/tree were picked on 13 June 2018).

Mechanical thinning was performed using a manual gasoline-powered branch shaker [Vibroli; NTA, Sant Boi de Llobregat, Spain (similar to SC800; Cifarelli, Voghera, Italy)] designed for fruit harvesting $(2.1 \mathrm{~kW}$; stroke, $60 \mathrm{~mm}$; weight, $11 \mathrm{~kg}$ ) with a $2-\mathrm{m}$ pole with a terminal $40-\mathrm{mm}$ wide hook (Fig. 1). This device is used to assist the operator when detaching the fruit by grasping the branch and generating vibration by means of a gear crank mechanism. The amount of detached fruit during mechanical harvesting was estimated by visual control. According to the number of detached fruit counted after shaking each branch, the intensity of the following branch shake on the same tree was estimated. However, the exact thinning percentage was not calculated until the total number of detached fruit was counted at harvest. Canvases were located under the trees to collect detached fruit. A total of 4 to 10 branches on each tree were shaken using a very short vibration cycle (less than $1 \mathrm{~s}$ ). When the number of detached fruit was very low, a second vibration that was very short was applied. The operation was recorded with a camcorder to measure the time needed to shake the tree and to count the number of branches shaken on each tree.

A USB-triaxial accelerometer (X200-4; Gulf Coast Data Concepts, Waveland, MS) was used to register the accurate vibration frequencies. It includes a digital three-axis 200-g accelerometer capable of measuring acceleration and time. The accelerometer was located on the branch, close to the gripping point, to determine the vibration frequency and duration. Recorded frequencies were between 14 and $23 \mathrm{~Hz}$, the peak-topeak displacement of the branch at the gripping point varied from 35 to $39 \mathrm{~mm}$, and the vibration time ranged from 0.5 to $l \mathrm{~s}$. The peak acceleration registered at the gripping point was between 500 and $700 \mathrm{~m} \cdot \mathrm{s}^{-2}$.

The average time needed to thin a tree by using the two procedures was measured using a video recording. The hourly cost of a hand-held gasolinepowered shaker was calculated following the standards of the American Society of Agricultural and Biological Engineers (2014a, 2014b). The workforce cost in Spain during 2016-18 was $\approx \$ 9.9 / \mathrm{h}(\$ 0.165 / \mathrm{min})$. The hourly cost of a hand-held gasoline-powered shaker was calculated considering a machine life of 6 years or $1500 \mathrm{~h}$ of use (commercially available price of $\$ 1650$ ), an annual usage of $250 \mathrm{~h}$, an interest rate of $5 \%$, a salvage value of $15 \%$ of the purchase price, a cumulative repair and maintenance cost at $58 \%$ of the purchase price, and gasoline cost of $\$ 0.66 / \mathrm{h}$. The cost of the mechanical device was $\$ 2.244 / \mathrm{h}$, and the total cost of thinning with the device was estimated to be $\$ 12.144 / \mathrm{h}(0.2024 € / \mathrm{min})$.

Data analysis. Two factors were studied (thinning treatment 


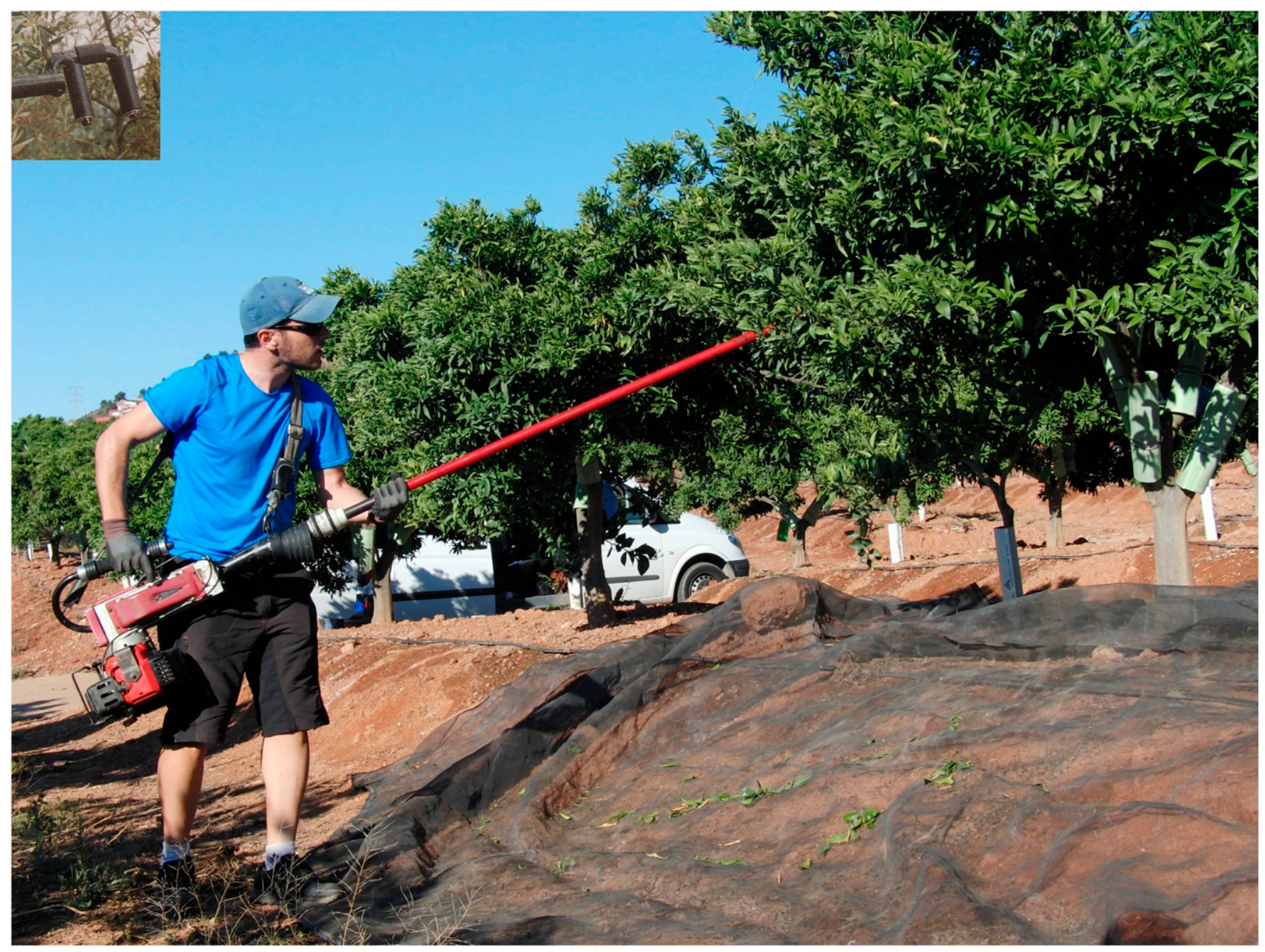

Fig. 1. Hand-held gasoline-powered shaker used for the mechanical thinning of 'Clemenrubi' mandarin and the details of the hook (upper left).

and year) and two variables were measured at harvest [individual fruit weight (grams per fruit) and fruit yield by weight (kilograms per tree)]. The first variable is referred to as "final fruit size," and the second variable is referred to as "final fruit yield." For the variable final fruit yield, the experimental unit was the tree. However, for the variable final fruit size, the experimental unit was the fruit; a sample of 50 randomly selected fruit were tested from each tree. A two-way analysis of variance (ANOVA) was performed to assess the effects of the thinning method and the year on the final fruit size and final fruit yield. Tukey's honestly significant difference test intervals were used to compare the mean values of final fruit size using the three thinning methods (mechanical thinning, manual thinning, and no thinning). In addition, during the thinning operation in 2018 , two samples of 50 randomly selected fruit $(50$ fruit before mechanical thinning and 50 detached by mechanical thinning) were measured to compare the size of the remaining fruit to the size of the detached fruit using a mean difference $t$ test.

\section{Results}

EfFiciency, THINNing costs, AND TREE DAMAGE. With mechanical thinning during the 3 years, the average time needed to shake a tree was $1.9 \mathrm{~min} /$ tree, and an average of 6.5 branches/tree were shaken (Table 2). Therefore, mechanical thinning of a 'Clemenrubi' tree cost $1.8 \mathrm{~min} /$ tree $\times \$ 0.2024 / \mathrm{min}=\$ 0.3643 /$ tree, independent of the number of detached fruit.

With manual thinning, using data from the 2016 commercial thinning pass, the average time required was 8 to $12 \mathrm{~min} /$ tree. It is common to perform the thinning operation one to three times per year (personal communication with the producers). Fruit with diameters smaller than $20 \mathrm{~mm}$ are usually detached during the first thinning operation (June). During the second thinning operation (July), fruit smaller than $30 \mathrm{~mm}$ are removed. In addition, during the third thinning operation (August), only defective fruit are removed. In the case of manual thinning, the time necessary to thin a tree depends on the number of detached fruit; however, the typical rate for this variety is approximately $10 \mathrm{~min} /$ tree. Therefore, the cost of thinning a 'Clemenrubi' tree can be estimated as $10 \mathrm{~min} /$ tree $\times$ $\$ 0.165 / \mathrm{min}=\$ 1.65 /$ tree .

Consequently, the ratio of the manual thinning cost to the mechanical thinning cost is $1.65 / 0.36=4.5$. The 
Table 2. Analysis of variance results outlining the number of branches of 'Clemenrubi' mandarin shaken per tree and the time necessary per tree for the entire mechanical thinning process for multiple trees during the different studied years $(2016,2017$, and 2018$)$.

\begin{tabular}{lcccccc}
\hline & \multicolumn{7}{c}{ Yr } & & & \\
\cline { 2 - 7 } & $\mathbf{2 0 1 6}$ & $\mathbf{2 0 1 7}$ & $\mathbf{2 0 1 8}$ & df & F & $\boldsymbol{P}$ \\
\hline Shaken branches (no./tree) & $5.3 \mathrm{a}^{\mathrm{z}}$ & $6.1 \mathrm{a}$ & $8.0 \mathrm{~b}$ & 2 & 4.38 & 0.02 \\
Time necessary to shake a tree $(\mathrm{min})$ & $1.6 \mathrm{a}$ & $1.9 \mathrm{a}$ & $2.2 \mathrm{a}$ & 2 & 0.56 & 0.58 \\
\hline
\end{tabular}

${ }^{\mathrm{z}}$ Means with the same letters within rows are not significantly different according to Tukey's honestly significant difference test at $P<0.05$.

\section{Proportion of the fruit diameters in mechanically thinned trees}

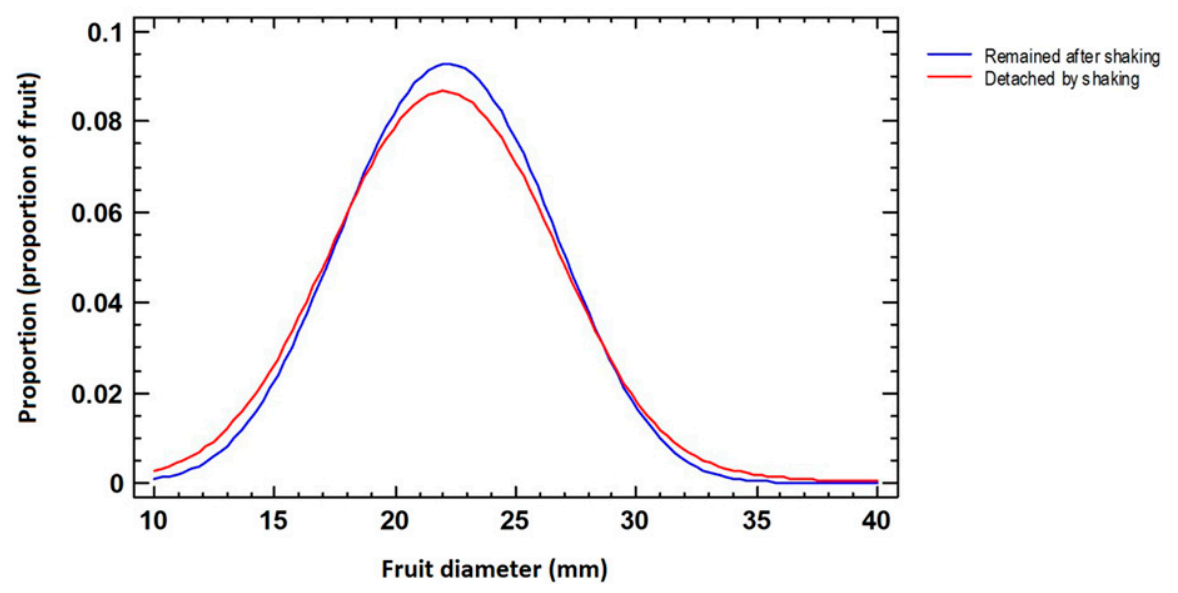

Fig. 2. Proportions of the diameters of fruit of mechanically thinned 'Clemenrubi' mandarin trees that remained after shaking (blue line) and were detached by shaking (red line) in 2018. The abscissa shows the fruit size and the ordinate shows the proportion of observations; $1 \mathrm{~mm}=0.0394$ inch.

Table 3. Analysis of variance results outlining the final fruit size of 'Clemenrubi' mandarin according to the type of thinning treatment $(\mathrm{N}=$ no thinning, $\mathrm{V}=$ vibratory mechanical thinning, $M=$ manual thinning) and year $(2016,2017$, and 2018).

\begin{tabular}{lcccc}
\hline & Avg final fruit size $(\mathrm{g} / \text { fruit })^{\mathrm{z}}$ & df & F & $P$ \\
\hline Thinning treatment & $62.56 \mathrm{a}^{\mathrm{y}}$ & 2 & 16.22 & 0.00 \\
$\mathrm{~N}$ & $68.11 \mathrm{~b}$ & & & \\
$\mathrm{~V}$ & $67.74 \mathrm{~b}$ & & & \\
$\mathrm{M}$ & & 2 & 11.13 & 0.00 \\
$\mathrm{Yr}$ & $61.50 \mathrm{a}$ & & & \\
2016 & $72.34 \mathrm{~b}$ & & & \\
2017 & $63.98 \mathrm{a}$ & & & \\
2018 & & & & \\
\hline
\end{tabular}

${ }^{\mathrm{z}} 1 \mathrm{~g}=0.0353 \mathrm{oz}$.

${ }^{y}$ Means with the same letters within columns are not significantly different according to Tukey's honestly significant difference test at $P<0.05$.

differential cost between both thinning systems can be $\$ 1.65 /$ tree (manual) $\$ 0.36 /$ tree $($ mechanical $)=\$ 1.29 /$ tree . In terms of the orchard area, the cost is $\$ 1.29 /$ tree $\times 980$ trees $/$ ha $=\$ 1261 /$ ha, showing a cost reduction in favor of mechanical thinning. Another important point is the reduction of time required to complete the work using mechanical thinning: one thinning pass can be performed five-times faster than an average manual pass. This factor is considered equally as important as cost reduction.
The shaking device did not cause any damage to the branches. Only minor damage was seen in some cases near the gripping point. No loss of leaves was noted.

Mechanical thinning did not detach the biggest fruit. The fruit size of the mechanically detached fruit from each tree followed a normal distribution. In 2018, diameters of the mechanically detached fruit from each tree were compared with the fruit on the tree before shaking. The mean difference $t$ test $(P>0.05)$ showed that there was no significant difference in size between the detached fruit and the fruit on the tree before shaking (Fig. 2). This result shows that mechanical thinning does not discriminate according to fruit size; it simply reduces the number of fruit of all sizes on the tree. This could be due to the largest fruit having both the greatest force during shaking and the greatest force required for fruit detachment (Romano et al., 2019).

COMPARISON B ETWEEN MECHANICAL THINNING AND MANUAL THINNING IN TERMS OF FINAL FRUIT SIZE AND FINAL FRUIT YIELD. In the preliminary trials developed in 2016, only late and very high-intensity thinning operations were studied after a previous manual thinning. The no thinning treatment showed significantly higher final fruit yield compared with mechanical and manual thinning. However, mechanical thinning showed a significantly higher final fruit size $(64.50 \mathrm{~g} /$ fruit $)$ using mechanical thinning compared with manual thinning $(58.56 \mathrm{~g} /$ fruit $)$ and no thinning $(58.50 \mathrm{~g} /$ fruit $)$ $(P=0.02)$.

To determine if these results were confirmed without previous manual thinning, tests were performed in 2017 and 2018. However, 2017 had an extremely high fruit yield by weight compared with 2018 $(64.2 \mathrm{~kg} /$ tree in 2017 compared with $51.2 \mathrm{~kg} /$ tree in $2018 ; P=0.01$; considering only the nonthinned trees). Final fruit size in 2017 was also significantly higher than that in 2018 (67.77 g/fruit in 2017 compared with $60.52 \mathrm{~g} /$ fruit in $2018 ; P=$ 0.02 ; considering only the nonthinned trees). Because of these differences, the year factor was also considered.

The average thinning percentages (calculated at harvest) were $18 \%$ 
Table 4. Analysis of variance results outlining the final fruit yield ( $\mathrm{kg} / \mathrm{tree})$ of 'Clemenrubi' mandarin according to the type of thinning treatment $(\mathrm{N}=$ no thinning, $\mathrm{V}=$ vibratory mechanical thinning, $\mathrm{M}=$ manual thinning) and year (2016, 2017, and 2018).

\begin{tabular}{lcccc}
\hline & Avg final fruit yield $(\mathrm{kg} / \mathrm{tree})^{\mathrm{z}}$ & df & F & $P$ \\
\hline Thinning treatment & $54.8 \mathrm{a}^{\mathrm{y}}$ & 2 & 2.07 & 0.13 \\
$\mathrm{~N}$ & $48.7 \mathrm{a}$ & & & \\
$\mathrm{V}$ & $50.4 \mathrm{a}$ & & & \\
$\mathrm{M}$ & & 2 & 77.25 & 0.00 \\
$\mathrm{Yr}$ & $62.6 \mathrm{a}$ & & & \\
2016 & $68.1 \mathrm{~b}$ & & & \\
2017 & $67.6 \mathrm{~b}$ & & & \\
2018 & & & & \\
\hline
\end{tabular}

${ }^{\mathrm{z}} 1 \mathrm{~kg}=2.2046 \mathrm{lb}$.

${ }^{\mathrm{y}}$ Means with the same letters within columns are not significantly different according to Tukey's honestly significant difference test at $P<0.05$.

in 2017 and $11 \%$ in 2018 , thus indicating low-intensity thinning.

A two-way ANOVA was performed to assess the effects of thinning treatments on the final fruit size as well as to consider the year factor (Table 3). Significant differences were found in the effects of thinning treatments and year. Significant differences were also found in the interaction effect $(P=0.05)$, indicating possible different behaviors between years. Excluding the significant differences in the productivity of the two years studied, the type of thinning treatment affected the final fruit size. The non thinned trees had a lower final fruit size than the thinned trees, regardless of whether they were mechanically or manually thinned. The final fruit size was significantly lower with the no thinning treatment compared with the thinning treatments. No significant differences in the final fruit size were found between the two thinning treatments (mechanical and manual).

The ANOVA results outlined that the final fruit yield was slightly lower with the mechanical treatment compared with the manual and no thinning treatments (average values of $48.7 \mathrm{~kg} /$ tree for mechanical thinning compared with $50.4 \mathrm{~kg} /$ tree and $54.8 \mathrm{~kg} /$ tree for manual and non thinning treatments, respectively) (Table 4). However, no significant differences in the final fruit yield were found between the different treatments.

\section{Discussion}

Citrus producers are usually not sure about the best thinning date and intensity because, for each variety, year, and development stage, the best option is different. In addition, the most important unknown factor at the time of thinning is the market demand at harvest time. During the years with high demand, all fruit sizes are accepted; however, during years with low demand, almost no size is accepted. Therefore, it is important to consider whether the increase in size obtained with thinning compensates for the work involved in performing it and the consequent loss of production. A reasonable strategy for citrus producers could be an early, low-intensity mechanical thinning operation, which involves a lower cost and a lower reduction in fruit yield by weight. This operation could reduce the amount of low-quality and defective fruit, and it could be used to guide citrus producers' decisions regarding possible late thinning.

Low-intensity mechanical thinning could increase the fruit size and reduce operation costs. A reduction of the final fruit yield with a lower cost per tree was not demonstrated. Therefore, mechanical thinning could be recommended to reduce labor costs and increase the fruit price because it is related to the high-quality fruit, resulting in larger profits for the producers.

\section{Conclusions}

Mechanical citrus thinning using a branch shaker was performed without damaging the tree. The mechanical operation was four- to five-times faster than manual thinning, with a similar hourly cost.

Moreover, no significant differences were found in the final fruit yield of thinned and non thinned trees. The final fruit size was significantly lower with the no thinning treatment compared with the manual and mechanical thinning treatments. However, no significant differences were found in the final fruit size with mechanical and manual thinning treatments.

Low-intensity mechanical thinning was capable of increasing the fruit size and reducing operation costs; however, a reduction of the final fruit yield using mechanical thinning was not observed. In conclusion, the use of a branch shaker could be recommended for thinning operations to increase efficiency and reduce labor costs while obtaining higherquality fruit, thus resulting in larger profits for producers.

\section{Literature cited}

Agustí, M. and V. Almela. 1984. Mejora de la calidad del fruto de la mandarina Satsuma. Banco de Santander, Madrid, Spain.

Agustí, M., A. Martínez-Fuentes, C. Mesejo, M. Juan, and V. Almela. 2003. Cuajado y desarrollo de los frutos cítricos. Generalitat de Valencia, Consellería de Agricultura, Pesca y Alimentació. Editorial Serie de Divulgación Técnica 55.

Agustí, M. 2003. Citricultura. MundiPrensa Editorial, Madrid, Spain.

American Society of Agricultural and Biological Engineers. 2014a. ASABE standards. D497.7. Agricultural machinery management data. Amer. Soc. Agr. Biol. Eng., St. Joseph, MI.

American Society of Agricultural and Biological Engineers. 2014b. ASABE. D496.3. Agricultural machinery management. Amer. Soc. Agr. Biol. Eng., St. Joseph, MI.

Berlage, A.G. and R.D. Langmo. 1982. Machine vs. hand thinning of peaches. Trans. ASAE 25:538-543, doi: 10.13031/ 2013.33569.

Davis, K., E. Stover, and F. Wirth. 2004. Economics of fruit thinning: A review focusing on apple and citrus. HortTechnology 14:282-289, doi: 10.21273/ HORTTECH.14.2.0282.

Damarow, L., A. Kunz, and M. Blanke. 2007. Regulation of fruit set by mechanical flower thinning. Erwerbs-Obstbau 49(1):1-9, doi: 10.1007/s10341-0070029-9.

Diezma, B. and U.A. Rosa. 2005. Monitoring of fruit removal for mechanical thinning of peaches. Proc. Info. Technol. 
Sustainable Fruit Veg. Production. 16 Sept. 2005. Montpellier, France. p. 165172.

Glozer, K. and J. Hasey. 2006. Mechanical thinning in cling peach. HortScience 41:995 (abstr.), doi: 10.21273/ HORTSCI.41.4.995D.

González-Rossia, D., C. Reig, M. Juan, and M. Agustí. 2007. Horticultural factors regulating effectiveness of GA3 inhibiting flowering in peaches and nectarines (Prunus persica L. Batsch). Scientia Hort. 111:352-357, doi: 10.1016/ j.scienta.2006.11.001.

Greene, D. and G. Costa. 2013. Fruit thinning in pome- and stone-fruit: State of the art. Acta Hort. 998:93-102, doi: 10.17660/ActaHortic.2013.998.10.

Guardiola, J.L. and A. García-Luis. 2000. Increasing fruit size in citrus. Thinning and stimulation of fruit growth. Plant Growth Regulat. 31:121-132, doi: 10.1023/ A:1006339721880.

Martín, B., A. Torregrosa, and J. GarcíaBrunton. 2010. Post-bloom thinning of peaches for canning with hand-held mechanical devices. Scientia Hort. 125: 658-665, doi: 10.1016/j.scienta.2010. 05.025 .

Mesejo, C., A. Martínez-Fuentes, M. Juan, V. Almela, and M. Agustí. 2003. Vascular tissues development of citrus fruits peduncle is promoted by synthetic auxins. Plant Growth Regulat. 39:131135, doi: 10.1023/A:1022520618786.

Mesejo, C., S. Rosito, C. Reig, A. Martinez-Fuentes, and M. Agustí. 2012. Synthetic auxin 3,5,6-TPA provokes citrus clementina (Hort. ex Tan) fruitlet abscission by reducing photosynthate availability. J. Plant Growth Regul. 31:186-194, doi: 10.1007/s00344-011-9230-z.

Ortiz, C., B. Martín-Gorriz, E. Ortí, and A. Torregrosa. 2016. An approach to mechanical thinning of mandarins. Proc. Amer. Soc. Agr. Biol. Eng. Annu. Intl. Mtg. 162457303.

Ortiz, C., E. Orti, S. Balasch, B. MartínGorriz, and A. Torregrosa. 2017. Análisis del aclareo mecánico de mandarinas a través de los vídeos de desprendimiento en laboratorio. Proc. IX Congreso Ibérico de Agroingeniería. p. 447-454.

Ouma, G. 2012. Fruit thinning with specific reference to citrus species: A review. Agr. Biol. J. N. Amer. 3:175-191, doi: 10.5251/abjna.2012.3.4.175.191.

Powell, A.A., B.G. Hancock, E.E. Puls, S.G. Helmers, and M.H. Brown. Jr. 1975.
Utilizing mechanical fruit thinning in commercial peach orchards. HortScience 10:142.

Roche, L. and A. Masseron. 2002. Éclaircissage mécanique des boutons floraux: Darwin et le Mur fruitier. Infos CTIFL 185:29-33.

Romano, A., A. Torregrosa, S. Balasch, and C. Ortiz. 2019. Mechanical mandarin thinning related to fruitlet developing stage. Proc. X Congreso Ibérico de Agroingeniería. doi: 10.26754/c_agroing.2019.com.3300.

Schupp, J.R., T. Auxt Baugher, S.S. Miller, R.M. Harsh, and K.M. Lesser. 2008. Mechanical thinning of peach and apple trees reduces labor input and increases fruit size. HortTechnology 18:660-670, doi: 10.21273/HORTTECH.18.4.660.

Stover, E., S. Ciliento, M. Ritenour, and C. Counter. 2002. NAA thinning of 'Murcott': Comparison of small plot and commercial harvest data. Proc. Florida State Hort. Soc. 115:287-291.

Torregrosa, A., E. Ortí, S. Balasch, and C. Ortiz. 2017. Aclareo mecánico de mandarinas 'Clemenrubí' con un vibrador de ramas. Proc. IX Congreso Ibérico de Agroingeniería. p. 340-349. 